\title{
An Antigenic Analysis for Membranes of Mycoplasma hominis by Cross-absorption
}

\author{
By JUEY-SHIN L. LIN \\ Channing Laboratory and Department of Medicine, Harvard Medical School and \\ Peter Bent Brigham Hospital, Division of the Affiliated Hospitals Center Inc., \\ Boston, Massachusetts 02115, U.S.A.
}

(Received 21 March 1979; revised 5 July 1979)

\begin{abstract}
Antigenic components at the outer surface membranes of seven serotypes of Mycoplasma hominis were analysed by the mycoplasmacidal reaction and the agglutination during growth reaction. Antibody absorbing capacities of the mycoplasma cells were compared with the absorbing capacities of membranes. It was shown that serologically active membrane antigens were mainly heat-labile proteins. No major antigens common to all seven serotypes were detected and each strain had its own specific antigens at the cell surface. Results of analysis indicate that there is a complex antigenic structure exposed in $M$. hominis and that 7 to 14 cross-reacting antigens may be present at the outer surface in the different serotypes examined. Additional cross-reacting antigens, presumably inner membrane in origin and not exposed at the cell surface, were also demonstrable.
\end{abstract}

\section{INTRODUCTION}

Serological heterogeneity within strains of Mycoplasma hominis had been demonstrated repeatedly (Purcell et al., 1969). Recently, M. hominis was shown to consist of at least seven serotypes by the mycoplasmacidal (MC), the agglutination during growth (GA) and the growth inhibition (GI) tests (Lin \& Kass, 1974; Lin et al., 1975), and more than 200 strains of $M$. hominis were serotyped using the GA test and antisera from the seven serotypes (Lin et al., 1976). It is of interest that all these tests showing strain specificities require live cells for the serological reactions to be evident. Since mycoplasmas do not have cell walls (Razin, 1973), the serological heterogeneity suggests a complex antigenic structure of the surface membrane. Therefore, an analysis was undertaken of the MC and GA antigens at the outer surface of $M$. hominis. This paper presents the results of such an analysis and shows that there are at least 7 to 14 different antigens at the outer surface of the different serotypes of M. hominis.

\section{METHODS}

Reference strains and antisera. The origins of the seven reference strains of $M$. hominis were described previously (Lin et al., 1975). They are designated as serotypes 1 to 7. Mycoplasmas were grown in a basic medium containing $70 \%(\mathrm{v} / \mathrm{v})$ PPLO broth, $20 \%(\mathrm{v} / \mathrm{v})$ horse serum, $10 \%(\mathrm{v} / \mathrm{v})$ yeast extract, $0.002 \%(\mathrm{w} / \mathrm{v})$

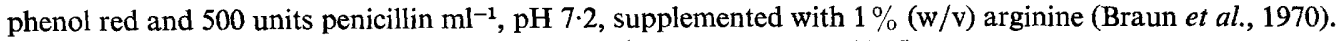
Antisera against each strain were prepared in rabbits (Lin \& Kass, 1975).

Cell and membrane preparations. Overnight cultures which contained $10^{9}$ to $10^{10} 50 \%$ colour changing units of organisms $\mathrm{ml}^{-1}$ (c.c.u. $\mathrm{ml}^{-1}$ ) (Lin \& Kass, 1970) were centrifuged at $15000 \mathrm{~g}$ for $30 \mathrm{~min}$. The cells were washed twice with and suspended in phosphate-buffered saline (PBS; 0.02 M-phosphate, pH 6.8) and were used directly to absorb sera. The final cell preparations contained $10^{11}$ to $10^{12}$ c.c.u. mycoplasmas $\mathrm{ml}^{-1}$ and 8 to $12 \mathrm{mg}$ protein $\mathrm{ml}^{-1}$, determined by Lowry's method using crystalline bovine serum albumin as standard. The remaining cells were stored at $-70^{\circ} \mathrm{C}$ for the preparation of membrane fractions.

Membrane fractions were isolated essentially according to the procedure of Hollingdale \& Lemcke (1969). 
Cell preparations were diluted with an equal volume of PBS and treated for $3 \mathrm{~min}$ with a 9KC Ratheon sonic oscillator at maximum intensity. The sonicated cells were centrifuged at $15000 \mathrm{~g}$ for $30 \mathrm{~min}$ and the pellets, presumably unbroken cells, were resuspended in the same volume of PBS and sonicated again. A total of three sonications were performed in this manner and the combined supernatants were centrifuged at $40000 \mathrm{~g}$ for $30 \mathrm{~min}$. The pellets were washed twice with and resuspended in PBS and stored at $-70^{\circ} \mathrm{C}$. The membrane fractions derived from $10^{11}$ to $10^{12}$ c.c.u. mycoplasmas $\mathrm{ml}^{-1}$ usually contained 0.5 to $1.0 \mathrm{mg}$ protein $\mathrm{ml}^{-1}$. The final preparations contained few or no viable cells $(<10$ c.c.u. $)$.

Measurement of serological activity. Serological tests were conducted using the microtitre system previously described (Lin \& Kass, 1974). Both MC and GA tests were performed with $10^{1}$ to $10^{2}$ c.c.u. antigens. All the sera were heat-inactivated at $56{ }^{\circ} \mathrm{C}$ for 30 min prior to the tests. Fresh guinea pig sera which had a haemolytic activity of $\geqslant 500$ units (Kabat \& Mayer, 1961) were included as complement sources in the MC tests. Twofold serial dilutions of serum were tested and the reciprocal of the highest dilution of serum in which serological activities were demonstrated was used to express antibody titre. Antibody titres to the serotype used for immunization are referred to as 'homologous' and those to other serotypes as 'heterologous'.

Treatment of cell preparations. The cells were treated in various ways in order to characterize the biochemical properties of the antigenic components: (i) a preparation was incubated with freshly prepared sodium periodate (final concn $5 \mathrm{mM}$ ) at room temperature for $1 \mathrm{~h}$ (Morgan \& Watkins, 1951) and then washed once with PBS or dialysed against PBS at $4{ }^{\circ} \mathrm{C}$ overnight; (ii) a preparation was incubated with trypsin [Difco, $1: 250$, final concn $0.2 \%$ (w/v), previously filtered through a $4 \mu \mathrm{m}$ Millipore filter] at $37^{\circ} \mathrm{C}$ for $30 \mathrm{~min}$; (iii) a preparation was freeze-thawed 10 times, alternating between dry ice in ethanol and a $37^{\circ} \mathrm{C}$ water bath; (iv) a preparation was incubated at $56^{\circ} \mathrm{C}$ for $30 \mathrm{~min}$.

Serum absorption. In order to absorb antibodies, $0.1 \mathrm{ml}$ of antisera were incubated with $0.3 \mathrm{ml}$ of the whole cell or membrane preparations at $37^{\circ} \mathrm{C}$ for $1 \mathrm{~h}$ and then centrifuged for $30 \mathrm{~min}$ at $9000 \mathrm{~g}$ to remove cells and at $40000 \mathrm{~g}$ to remove membranes. The supernatants were incubated further with $0.4 \mathrm{ml}$ of the same preparation at $4{ }^{\circ} \mathrm{C}$ overnight in a roller drum and re-centrifuged. In the final supernatants, the antiserum had been diluted to 1:8. Twofold serial dilutions of the preparations were tested with the homologous antiserum. The lowest concentrations of the cell and membrane preparations which reduced the homologous titre to $\leqslant 64$ were considered as containing 1 unit of antigen. Preparations containing 1 or 2 units of antigen were used to absorb concurrently the homologous antiserum, and the six heterologous antisera, respectively. Seven preparations which contained pooled membranes of six serotypes were prepared so that the final concentration of antigens for each serotype was equivalent to 1 to 2 units. The pooled preparations were used to absorb the homologous antiserum of the serotype which had not been included in the preparation. A fourfold or more decrease in titre after the absorption with heterologous cells was considered to be significant. Cell and membrane preparations having 1 to 2 units of antigen usually contained 1 to 2 and 0.5 to $1.0 \mathrm{mg}$ protein $\mathrm{ml}^{-1}$, respectively.

Analysis of antigenic components. It was assumed that antigens corresponding to antibodies which were absorbed by and interacted with whole cells were present at the cell surface. Thus, when a given cell preparation had significantly absorbed antibodies, the preparation shared an antigen with the serotype that was used as the test antigen in the serological test. This assumption was tested by reciprocal absorption. If the reciprocal absorption gave results similar to that expected from the initial studies, then the antigen was considered a major one. If the absorption was not reciprocal, then the antigen was considered as a minor one, i.e. present in too small an amount to absorb a significant amount of antibody but capable of inducing and reacting with antibodies. Major antigens were represented by capital letters A, B, C, D, E, F, G for serotypes $1,2,3,4,5,6$ and 7 , respectively and minor antigens were represented by small letters a, b, c, d, e, $\mathrm{f}, \mathrm{g}$. Thus, if cross-reacting activities of $\mathrm{BC}, \mathrm{CA}$ and $\mathrm{AB}$ were demonstrated in sera of serotypes 1,2 and 3 , respectively, then an antigen labelled $A B C$ would be present and shared by serotypes 1,2 and 3. Antigen $A$ does not cross-react with antigens $\mathrm{AB}$ or $\mathrm{ABC}$.

\section{RESULTS}

\section{Biochemical properties of membrane antigens}

Preparations of cell antigens were subjected to various treatments in order to achieve a basic characterization of their nature. Representative results of these studies with serotype 6 and the homologous antiserum are shown in Table 1. Most, if not all, of the absorbing capacities of the whole cells were destroyed by heating at $56{ }^{\circ} \mathrm{C}$ for $30 \mathrm{~min}$ and by exposure to trypsin. Treatment with periodate partially inactivated the capacities of the antigens to absorb GA antibodies. Repeated freeze-thawing did not alter the serological capacity of the cell preparations. The results indicated that the major antigens are heat-labile proteins, 
Table 1. Sensitivity of surface antigens of $M$. hominis (serotype 6) to various treatments

Titre after absorption with whole cells* that had been exposed to:

\begin{tabular}{|c|c|c|c|c|c|c|c|}
\hline \multirow[b]{2}{*}{ Serological test } & \multirow{2}{*}{$\begin{array}{c}\text { Titre } \\
\text { before } \\
\text { absorption }\end{array}$} & \\
\hline & & $\begin{array}{c}\text { No } \\
\text { treatment }\end{array}$ & $37^{\circ} \mathrm{C}$ & $56^{\circ} \mathrm{C}$ & $\begin{array}{l}\text { Freeze- } \\
\text { thawing }\end{array}$ & Periodate & Trypsin \\
\hline $\begin{array}{l}\text { Mycoplasmacidal } \\
\text { (MC) }\end{array}$ & 2048 & $\leqslant 16$ & $\leqslant 16$ & 4096 & 32 & $\leqslant 16$ & 2048 \\
\hline $\begin{array}{l}\text { Agglutination during } \\
\text { growth (GA) }\end{array}$ & 2048 & $\leqslant 32$ & $\leqslant 32$ & 2048 & $\leqslant 32$ & 256 & 1024 \\
\hline
\end{tabular}

* Whole cell preparations contained 1 to $2 \mathrm{mg}$ protein $\mathrm{ml}^{-1}$ or 1 unit of antigenic activity as defined in Methods.

Table 2. Differential antibody-absorbing capacities between cells and membrane antigens of $M$. hominis demonstrated in heterologous antisera

$\begin{array}{ccccc}\begin{array}{c}\text { Serotype of } \\ \text { absorbing antigen }\end{array} & \begin{array}{c}\text { Serotype of } \\ \text { antiserum absorbed }\end{array} & \text { Before absorption } & \text { Cells* } & \text { After absorption with: } \\ 2 & 6 & 4096 & 2048 & 128 \\ 2 & 7 & 16384 & 8192 & 1024 \\ 3 & 5 & 8192 & 16384 & 2048 \\ 3 & 6 & 4096 & 4096 & 512 \\ 6 & 5 & 16384 & 16384 & 512\end{array}$

* Each preparation contained 1 to 2 units of antigenic activity against the homologous antiserum as defined in Methods.

Table 3. Serotype-specific antibody* demonstrated in seven antisera of $M$. hominis after absorption of each serum with pooled membranes of the six heterologous serotypes

Serological
test
MC
GA

Antiserum
absorbed with:
PBS
Membranes
PBS
Membranes

\begin{tabular}{|c|c|c|c|c|c|c|}
\hline 1 & 2 & 3 & 4 & 5 & 6 & 7 \\
\hline $\begin{array}{r}8192 \\
256\end{array}$ & $\begin{array}{l}8192 \\
1024\end{array}$ & $\begin{array}{r}16384 \\
4096\end{array}$ & $\begin{array}{l}8192 \\
1024\end{array}$ & $\begin{array}{l}8192 \\
1024\end{array}$ & $\begin{array}{r}4096 \\
256\end{array}$ & $\begin{array}{r}8192 \\
512\end{array}$ \\
\hline $\begin{array}{l}2048 \\
1024\end{array}$ & $\begin{array}{r}16384 \\
4096\end{array}$ & $\begin{array}{r}4096 \\
512\end{array}$ & $\begin{array}{r}2048 \\
512\end{array}$ & $\begin{array}{l}8192 \\
4096\end{array}$ & $\begin{array}{l}2048 \\
2048\end{array}$ & $\begin{array}{r}1024 \\
256\end{array}$ \\
\hline
\end{tabular}

* Very low titres $(\leqslant 64)$ to the other six heterologous serotypes.

that polysaccharides may be involved in the GA reaction and that lipids are not significantly involved as antigens.

\section{Absence of common antigens}

When the six heterologous cell preparations were used to absorb each of the seven sera, respectively, there was no significant alteration of the homologous titre of the sera, indicating that there are no major antigens at the cell surface that are common to the seven serotypes of $M$. hominis. When membrane preparations were used in the same manner, those obtained from serotypes 1, 4 and 5 also did not alter the homologous titres of the six antisera, whereas those from serotypes 2, 3, 6 and 7 significantly lowered the homologous MC titres of some sera (Table 2). Lowering of antibody titres by the latter membrane fractions was not caused by non-specific inactivation of antibodies, since a large proportion of antisera were not affected. Presumably therefore, some cross-reacting antigens are present in the membrane preparations of serotypes 2, 3, 6 and 7 but these are not expressed at the outer surface of the cells. 
Table 4. Absorption of antibodies from antiserum to $M$. hominis serotype 1 by heterologous cells

\begin{tabular}{|c|c|c|c|c|c|c|c|}
\hline \multirow{2}{*}{$\begin{array}{l}\text { Serotype } \\
\text { of antigens } \\
\text { used for } \\
\text { test }\end{array}$} & \multicolumn{7}{|c|}{ Serotype of cells used for absorption } \\
\hline & None & 2 & 3 & 4 & 5 & 6 & 7 \\
\hline & \multicolumn{7}{|c|}{ MC titre after absorption } \\
\hline 1 & 8192 & 8192 & 8192 & 4096 & 8192 & 4096 & 8192 \\
\hline 2 & 8192 & $\leqslant 64$ & 4096 & 512 & 4096 & 2048 & 1024 \\
\hline 3 & 8192 & 512 & $\leqslant 32$ & 1024 & 8192 & 512 & 1024 \\
\hline 4 & 8192 & 1024 & 4096 & $\leqslant 32$ & 4096 & 4096 & 1024 \\
\hline 5 & 8192 & 2048 & 1024 & 1024 & $\leqslant 32$ & 4096 & 8192 \\
\hline 6 & 8192 & 1024 & 2048 & 2048 & 4096 & $\leqslant 32$ & 512 \\
\hline \multirow[t]{2}{*}{7} & 8192 & 2048 & 8192 & 2048 & 8192 & 4096 & $\leqslant 32$ \\
\hline & \multicolumn{7}{|c|}{ GA titre after absorption } \\
\hline 1 & 8192 & 1024 & 8192 & 1024 & 2048 & 1024 & 2048 \\
\hline 2 & 8192 & $\leqslant 64$ & 1024 & 512 & 4096 & 4096 & 2048 \\
\hline 3 & 2098 & $\leqslant 32$ & $\leqslant 32$ & 64 & 1024 & 1024 & 256 \\
\hline 4 & 1024 & 128 & 128 & $\leqslant 32$ & 1024 & 1024 & 1024 \\
\hline 5 & 2048 & 256 & 2048 & 512 & $\leqslant 32$ & 1024 & 512 \\
\hline 6 & 512 & 64 & 256 & 256 & 512 & $\leqslant 64$ & 256 \\
\hline 7 & 128 & $\leqslant 32$ & $\leqslant 32$ & $\leqslant 32$ & 64 & $\leqslant 32$ & $\leqslant 32$ \\
\hline
\end{tabular}

Table 5. Absorption of antibodies from antiserum to $M$. hominis serotype 1 by heterologous membranes

\begin{tabular}{|c|c|c|c|c|c|c|c|}
\hline \multirow{2}{*}{$\begin{array}{l}\text { Serotype } \\
\text { of antigens } \\
\text { used for } \\
\text { test }\end{array}$} & \multicolumn{7}{|c|}{ Serotype of membranes used for absorption } \\
\hline & None & 2 & 3 & 4 & 5 & 6 & 7 \\
\hline & \multicolumn{7}{|c|}{ MC titre after absorption } \\
\hline 1 & 8192 & 4096 & 8192 & 4096 & 8192 & 8192 & 512 \\
\hline 2 & 8192 & $\leqslant 64$ & 8192 & 256 & 2048 & 512 & 2048 \\
\hline 3 & 8192 & 512 & $\leqslant 64$ & 2048 & 1024 & 256 & 256 \\
\hline 4 & 8192 & 512 & 2048 & $\leqslant 64$ & 512 & 256 & 2048 \\
\hline 5 & 8192 & 1024 & 256 & $\leqslant 64$ & $\leqslant 64$ & 512 & 4096 \\
\hline 6 & 8192 & 256 & 2048 & 1024 & 2048 & $\leqslant 64$ & 512 \\
\hline \multirow[t]{2}{*}{7} & 8192 & $\leqslant 64$ & 256 & 2048 & 4096 & 1024 & $\leqslant 64$ \\
\hline & \multicolumn{7}{|c|}{ GA titre after absorption } \\
\hline 1 & 8192 & 2048 & 4096 & 1024 & 2048 & 1024 & 4096 \\
\hline 2 & 8192 & $\leqslant 64$ & 2048 & $\leqslant 64$ & 4096 & 8192 & 2048 \\
\hline 3 & 2048 & 128 & $\leqslant 64$ & 128 & 1024 & 256 & 512 \\
\hline 4 & 1024 & 128 & 256 & $\leqslant 64$ & 1024 & 1024 & 512 \\
\hline 5 & 2048 & 512 & 1024 & $\leqslant 64$ & $\leqslant 64$ & 512 & 1024 \\
\hline 6 & 512 & $\leqslant 64$ & 512 & 256 & 512 & $\leqslant 64$ & 256 \\
\hline 7 & 128 & $\leqslant 64$ & $\leqslant 64$ & $\leqslant 64$ & $\leqslant 64$ & $\leqslant 64$ & $\leqslant 64$ \\
\hline
\end{tabular}

Serotype-specific antigens

The presence of type-specific antigens was demonstrated by absorbing each antiserum with the preparation which contained pooled membranes from six heterologous serotypes (Table 3). Each serum retained significant homologous antibody titres after the absorption but only low titres $(\leqslant 64)$ to the other six heterologous serotypes could be demonstrated. Relatively more MC than GA antibodies were removed from sera 1, 5, 6 and 7, results similar to those shown in Table 2. 
Table 6. Antigens detected in membranes of $M$. hominis by reciprocal absorption tests

\begin{tabular}{|c|c|c|c|c|c|}
\hline \multirow{2}{*}{$\begin{array}{c}\text { Serotype } \\
1\end{array}$} & \multicolumn{2}{|c|}{ Outer surface } & \multicolumn{2}{|c|}{ Inner surface $\dagger$} & \multirow{2}{*}{$\begin{array}{c}\text { Total } \\
17\end{array}$} \\
\hline & $\begin{array}{l}\mathrm{ABC}, \mathrm{ABG}^{*}, \mathrm{ACD} \\
\mathrm{ACE}, \mathrm{ACF}, \mathrm{ADG}, \\
\text { AFG }\end{array}$ & $\begin{array}{l}\text { ab, ac, ad, } \\
\text { AE, af, AG }\end{array}$ & $\mathrm{BD}, \mathrm{CG}, \mathrm{EG}$ & A & \\
\hline 2 & $\begin{array}{l}\mathrm{ABC}^{*}, \mathrm{ABG}^{*}, \mathrm{BCF}, \\
\mathrm{BCG}^{*}, \mathrm{BFG}\end{array}$ & $\begin{array}{l}\mathrm{AB}, \mathrm{BC}, \mathrm{BD}, \\
\text { be, BF, bg }\end{array}$ & $\begin{array}{l}\mathrm{AF}, \mathrm{DE}, \mathrm{DF}, \\
\mathrm{EF}, \mathrm{GE}\end{array}$ & $\mathrm{B}, \mathrm{C}, \mathrm{G}$ & 19 \\
\hline 3 & $\begin{array}{l}\mathrm{ABC}, \mathrm{ACD}, \mathrm{ACE} * \\
\mathrm{ACF}, \mathrm{CBF}, \mathrm{CBG} \\
\mathrm{CDF}, \mathrm{CFG}^{*}\end{array}$ & $\begin{array}{l}\text { AC, bc, CD, } \\
\text { ce, CF, CG }\end{array}$ & $\mathrm{AG}, \mathrm{DG}, \mathrm{EF}$ & C, E, F & 20 \\
\hline 4 & $\begin{array}{l}\mathrm{ACD}, \mathrm{ADG}^{*}, \mathrm{CDF}, \\
\text { DFG }\end{array}$ & $\begin{array}{c}\mathrm{AD}, \mathrm{bd}, \mathrm{CD}, \\
\mathrm{de}, \mathrm{DF}, \mathrm{dg}\end{array}$ & $\mathrm{AE}, \mathrm{AF}$ & $\mathrm{D}$ & 13 \\
\hline 5 & $\mathrm{ACE}^{*}$ & $\begin{array}{l}\text { ab, be, ce, } \\
\text { de, ef, eg }\end{array}$ & $\begin{array}{c}\mathrm{AB}, \mathrm{AD}, \mathrm{AG}, \\
\mathrm{BD}, \mathrm{BG}, \mathrm{CG}\end{array}$ & $\mathrm{E}$ & 14 \\
\hline 6 & $\begin{array}{l}\mathrm{ACF}^{*}, \mathrm{AFG}^{*}, \mathrm{BCF}^{*} \text {, } \\
\text { BFG, } \mathrm{CDF}^{*}, \mathrm{FDG}^{*}\end{array}$ & $\begin{array}{l}\text { af, bf, CF, } \\
\text { DF, ef, GF }\end{array}$ & $\underset{\mathrm{BE}}{\mathrm{AB}}, \mathrm{AD}, \mathrm{AE}$ & $\mathrm{F}, \mathrm{E}$ & 18 \\
\hline 7 & $\begin{array}{l}\text { ABG, AGD, AFG, } \\
\text { BFG, CFG, DFG }\end{array}$ & $\begin{array}{l}\text { AG, BG, cg, } \\
\text { DG, eg, FG }\end{array}$ & $\mathrm{BE}$ & G, A & 15 \\
\hline
\end{tabular}

\section{Antigenic components of membranes}

Titres after absorption of antibodies from antiserum to serotype 1 by heterologous cells are presented in Table 4 as a representative of the seven sera. The minimum number of cross-reacting antigens at the outer surface of the seven serotypes of $M$. hominis, estimated from the results of reciprocal absorptions, was 7 to 14 (Table 6). There were 15 antigens shared by three serotypes and 30 antigens shared by two serotypes. Various heterologous antibody activities, which were not absorbed or detected by the homologous cells, were present in all seven sera, indicating that some membrane antigens were not exposed at the cell surface. Antibodies to such antigens, if exposed at the inner surface, would be selectively absorbed by membranes but not by whole cells. Therefore, results of reciprocal absorptions with membranes (Table 5) were compared with those with cells (Table 4) and the antibodies which were absorbed preferentially by membranes were derived. Inner membrane antigens, which absorbed a significant amount of antibody from heterologous sera, invariably induced antibodies in the homologous serum. As summarized in Table 6, 3 to 8 such antigens were detected. In total, 13 to 20 membrane antigens were detected in each serotype of M. hominis.

\section{DISCUSSION}

Surface antigens of $M$. hominis active in the MC and GA reactions were inactivated by incubation at $56{ }^{\circ} \mathrm{C}$ for $30 \mathrm{~min}$ and by treatment with trypsin. Thus, serologically active antigens contain predominantly heat-labile proteins. Although periodate treatment lowered the antibody-absorbing capacity of cell preparations for the GA reaction, it is not certain whether carbohydrates participated in the GA reaction; some amino acids may react with periodate (Kabat \& Mayer, 1961). Repeated freeze-thawing failed to lower any of the antigenic activities of the preparation, suggesting that lipoproteins were not involved in the reactions. Past studies suggest that little or no glycolipid and glycoprotein occur in membranes of M. hominis (Rottem \& Razin, 1973; Schiefer et al., 1974). Results presented here were similar to those of Hollingdale \& Lemcke (1972) who treated membrane preparations of a strain of $M$. hominis in various ways and tested their antigenicity by the metabolism inhibition, indirect haemagglutination and gel diffusion tests. They showed that antigenicity 
was associated with non-lipid residues and probably consisted mainly of proteins. Antigenic components with various sensitivities to heat, alkali and periodates were also demonstrated.

Both the mycoplasmacidal reaction, i.e. killing of $M$. hominis by antibodies in the presence of complement, and the agglutination during growth of $M$. hominis in broth cultures in the presence of antibody (Lin \& Kass, 1974) require live cells to manifest the serological reactions. Therefore, antigens participating in these reactions are exposed at the outer surface of $M$. hominis. In the present experiments, live unfrozen cells were used to absorb antisera, indicating that the antigens which absorbed antibody from appropriate antisera are also located at the outer surface of the mycoplasmas. It is unlikely that much destruction of cells occurred during the process of antibody absorption. It has been shown that antibody to $M$. hominis agglutinated and inhibited the growth of mycoplasmas but only in the presence of complement were mycoplasmas killed by antibody (Lin \& Kaas, 1975). Although the membrane fractions used in the present experiments were not further characterized, it was presumed that cytoplasmic components were not involved (Razin, 1973). The results presented here are aimed not at identifying specific antigens or the number of antigens present in membranes of $M$. hominis, but merely to illustrate the antigenic heterogeneity of the species. The present methods of analysis are based on some assumptions which may not be quantitative. For example, 1 to 2 units of antigen activity may not be sufficient to remove minor antibody activities. It was also assumed that immunogenicity and absorbing capacity of antigens were equivalent. Moreover, the inner membrane components detected by using sonicated membrane fragments (Kahane \& Razin, 1969; Pollack et al., 1965) may not be optimal.

Serological heterogeneity within other species of mycoplasmas has been demonstrated in M. pulmonis (Forshaw \& Fallon, 1972), M. hyorhinis (Gois et al., 1974) and Ureaplasma urealyticum (Purcell et al., 1969; Black, 1970; Lin et al., 1972). The cross-reacting patterns demonstrated within each mycoplasmal species are as complex as in $M$. hominis. The high sensitivity and specificity of the MC and GA reactions made it possible to examine antigenic components of $M$. hominis in detail. Results presented here have shown that a total of 13 to 20 antigens are demonstrable by serological techniques in each serotype of $M$. hominis. Hollingdale \& Lemcke (1970) observed 12 to 15 protein bands and Amar et al. (1974) reported 18 different polypeptide bands in some strains of $M$. hominis using electrophoresis of detergent-lysed membrane preparations.

This work was supported by Public Health Service Research Grant No. HD-03693 from the National Institute of Child Health and Human Development. The author wishes to thank Ms Katalin Radnay for her technical assistance and Dr Edward H. Kass for reviewing the manuscript.

This paper was prepared in honour of Dr Edward H. Kass on his 60th birthday.

\section{REFERENCES}

Amar, A., Rottem, S. \& Razin, S. (1974). Characterization of mycoplasma membrane protein. IV. Disposition of proteins in the membrane. Biochimica et biophysica acta 352, 228-244.

BLACK, F. T. (1970). Serological methods for classification of human T-mycoplasmas. In Fifth International Congress on Infectious Diseases, Vienna, Austria, vol. 1, pp. 407-411. Vienna: Weiner Medizinische Akademie.

Braun, P., Klein, J. O., Lee, Y. H. \& Kass, E. H. (1970). Methodologic investigations and prevalence of genital mycoplasma in pregnancy. Journal of Infectious Diseases 121, 391-400.
ForSHAW, K. A. \& FAllon, R. J. (1972). Serological heterogeneity of Mycoplasma pulmonis. Journal of General Microbiology 72, 501-510.

Gois, M., Kuksa, T., Franz, J. \& TAylor-RobiNson, D. (1974). The antigenic differentiation of seven strains of Mycoplasma hyorhinis by growthinhibition, metabolism-inhibition, latex-agglutination and polyacrylamide-gel-electrophoresis tests. Journal of Medical Microbiology 7, 105115.

Hollingdale, M. R. \& Lemcke, R. M. (1969). The antigens of Mycoplasma hominis. Journal of Hygiene 67, 585-604. 
Hollingdale, M. R. \& Lemcke, R. M. (1970). Antigenic difference within the species Mycoplasma hominis. Journal of Hygiene 68, 469-477.

Hollingdale, M. R. \& LemCKe, R. M. (1972). Membrane antigens of Mycoplasma hominis. Journal of Hygiene 70, 85-98.

KABAT, E. A. \& MAYER, M. M. (1961). Effects of chemical treatment in altering immunochemical properties of proteins and polysaccharides. In Experimental Immunochemistry, pp. 445-465. Edited by E. A. Kabat \& M. M. Mayer. Springfield, Ill.: Charles C. Thomas.

KaHANe, I. \& Razin, S. (1969). Immunological analysis of mycoplasma membranes. Journal of Bacteriology 100, 187-194.

LIN, J.-S. \& KASS, E. H. (1970). Immune inactivation of T-strain mycoplasmas. Journal of Infectious Diseases 122, 93-95.

LIN, J.-S. \& KASs, E. H. (1974). Serological reactions of Mycoplasma hominis: differences among mycoplasmacidal, metabolic inhibition and growth agglutination tests. Infection and Immunity 10, 535-540.

LIN, J.-S. \& Kass, E. H. (1975). Complementdependent and complement-independent interactions between Mycoplasma hominis and antibodies in vitro. Journal of Medical Microbiology $\mathbf{8}$, 397-404.

Lin, J.-S., Kendrick, M. I. \& Kass, E. H. (1972). Serologic typing of human genital T-mycoplasmas by a complement-dependent mycoplasmacidal test. Journal of Infectious Diseases 126, 658-663.
Lin, J.-S., Alpert, S. \& RadNAY, K. M. (1975). Combined type-specific antisera in the identification of Mycoplasma hominis. Journal of Infectious Diseases 131, 727-730.

Lin, J.-S., Radnay, K., Kendrick, M. I. \& Kass, E. H. (1976). Serological studies on Mycoplasma hominis: serotypic distribution of recent clinical isolates. Scandinavian Journal of Infectious Diseases 8, 45-48.

Morgan, W. J. T. \& Watkins, W. M. (1951). The inactivation of the blood group receptors in the human erythrocyte surface by the periodate ion. British Journal of Experimental Pathology 32, $34-48$.

Pollack, J. D., Razin, S., Pollack, M. E. \& Cleverdon, R. C. (1965). Fractionations of mycoplasma cells for enzyme locations. Life Sciences 4, 973-999.

Purcell, R. H., Chanock, R. M. \& TAYloRRobINSON, D. (1969). Serology of the mycoplasmas of man. In The Mycoplasmatales and the L-Phase of Bacteria, pp. 221-264. Edited by L. Hayflick. New York: Appleton-Century-Crofts.

RaziN, S. (1973). Physiology of mycoplasmas. Advances in Microbial Physiology 10, 2-80.

RotTEM, S. \& RAZIN, S. (1973). Membrane lipids of Mycoplasma hominis. Journal of Bacteriology 113, 569-571.

Schiefer, H. G., Gerhardt, U., Brunner, H. \& KRÜPE, M. (1974). Studies with lectins on the surface carbohydrate structures of mycoplasma membranes. Journal of Bacteriology 120, 81-88. 